\title{
El procesamiento de imágenes: una herramienta de desarrollo
}

Christian Salamea Palacios Ingeniería Electrónica UPS-CUENCA
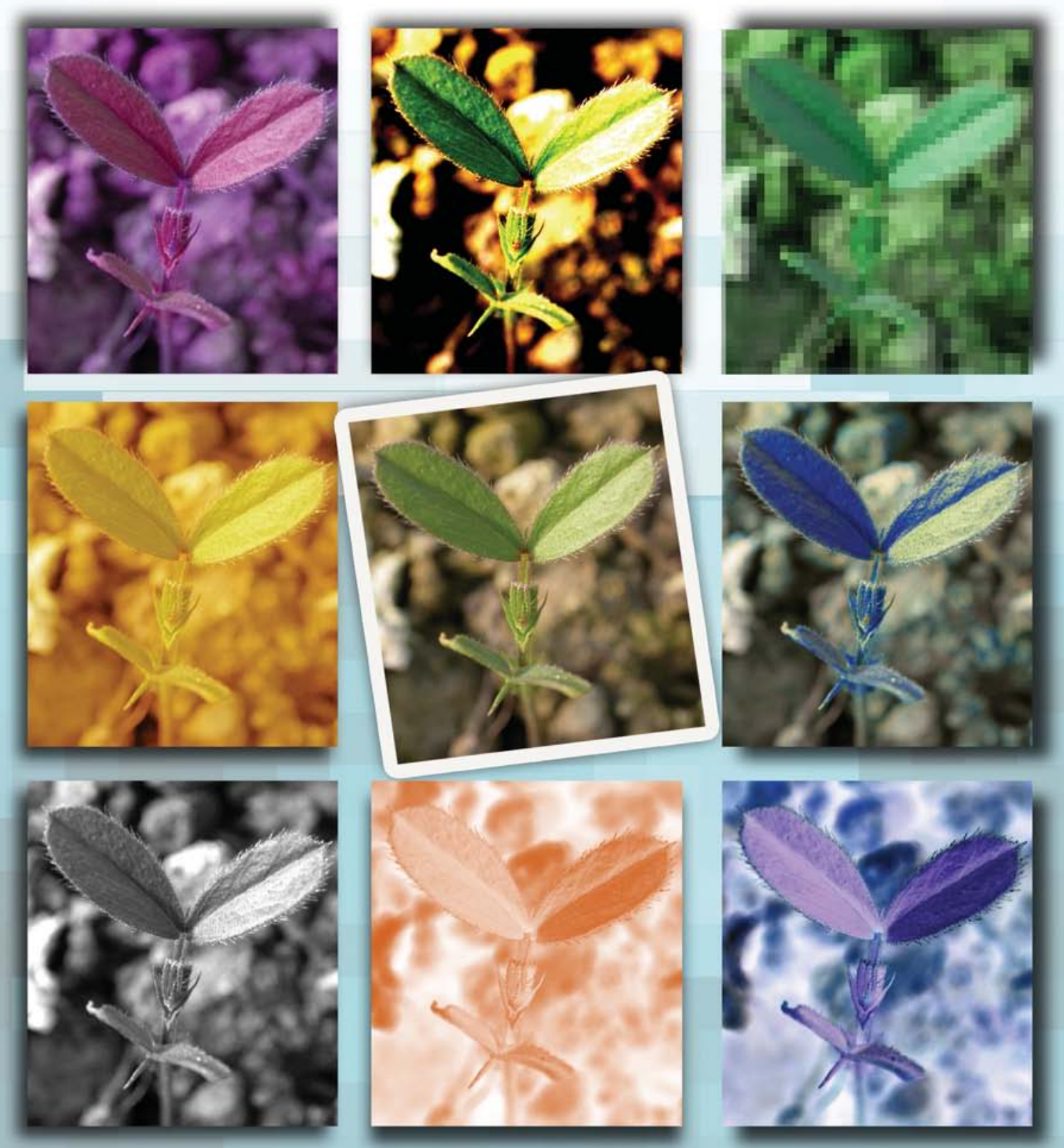

El presente documento describe la estructura general de un sistema de procesamiento de imágenes. 


\section{Introducción}

Utilizado desde principios de los ochenta por los Estados Unidos y desde finales de los noventa en el Tercer Mundo, el procesamiento de imágenes por computador ha revolucionado muchos procesos de la tecnología utilizada en la industria, lo podemos ver a diario en los software utilizados para el diseño de imágenes como el PAINT de Microsoft o el Illustrator de Adobe. La idea se basa en el mejoramiento de la calidad de imágenes tomadas en forma digital mediante el uso de un transductor para su posterior manipulación. Este transductor suele ser un CCD, pudiendo utilizar entonces para estas aplicaciones dispositivos que van desde la cámara casera de Video hasta la más compleja tarjeta capturadora de video.

En este documento se dará una visión general de todo el proceso para tratar a la imagen desde el mismo momento que llega al computador hasta la etapa final en la que se podrá reconocer e interpretar la imagen [Fig.1].

Tomando como base el uso del procesamiento de imágenes en una aplicación específica como la visión artificial [1], se definirán cada uno de los pasos necesarios para obtener un rendimiento óptimo en lo que se refiere al tratamiento de imágenes.



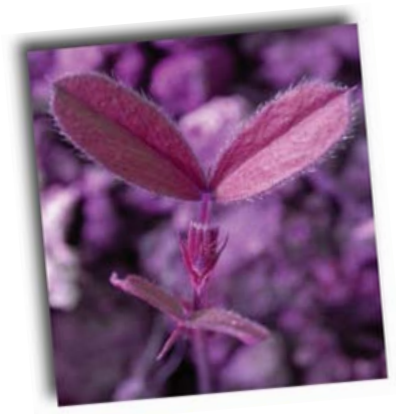

La idea se basa en el mejoramiento de la calidad de imágenes tomadas en forma digital mediante el uso de un transductor para su posterior manipulación.

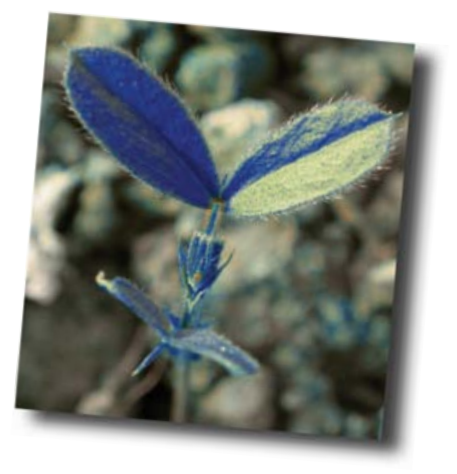

- La calibración.- Esta sección inicial se encuentra dentro del bloque de la adquisición de la imagen y es la encargada de tomar los datos desde un universo de posibilidades que por lo general se encuentran en tres dimensiones (largo, ancho y profundidad) y darle a cada uno de ellos una connotación específica, con la que se les pueda representar en dos dimensiones y con esto obtener datos manipulables en el computador.

- La umbralización.- Este segundo procedimiento es parte del preprocesamiento y se en- carga de estandarizar el nivel de claridad que emite cierta imagen para clasificarla entre un conjunto de posibilidades, para esto se utiliza por lo general histogramas de información con las que se obtienen las características fundamentales de la imagen.

- Filtrado.- El filtrado es fundamental para obtener información óptima de los datos que

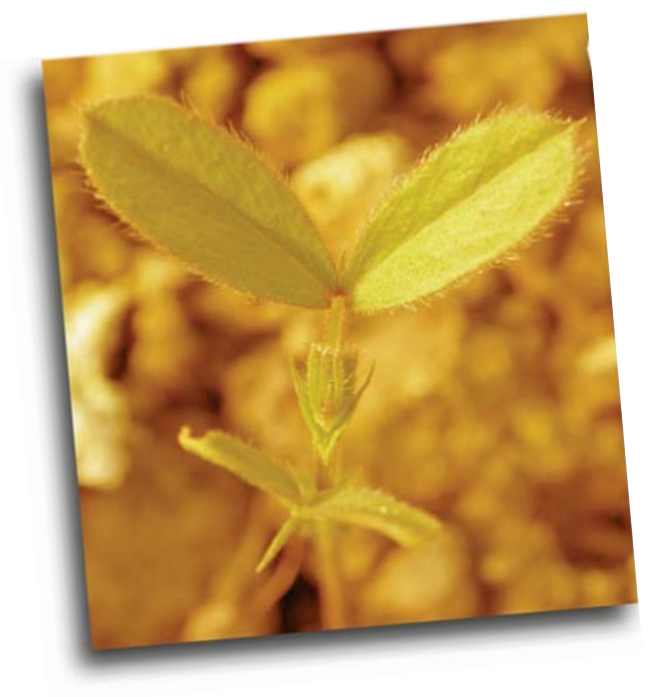

ingresan y que pueden ser perjudicados por la cantidad de ruido eléctrico presente. Estos filtros que se han utilizado son espaciales y frecuenciales.

- Segmentación.- Los histogramas de información también se pueden utilizar como referencia para "encerrar" porciones de imágenes con un mismo nivel de claridad y con esto definir la estructura general de la imagen.

- Etiquetado.- A cada porción se le asigna una numeración, con lo cual se puede conseguir el número exacto de componentes en una imagen, para su posterior interpretación. 


\section{Resultados}

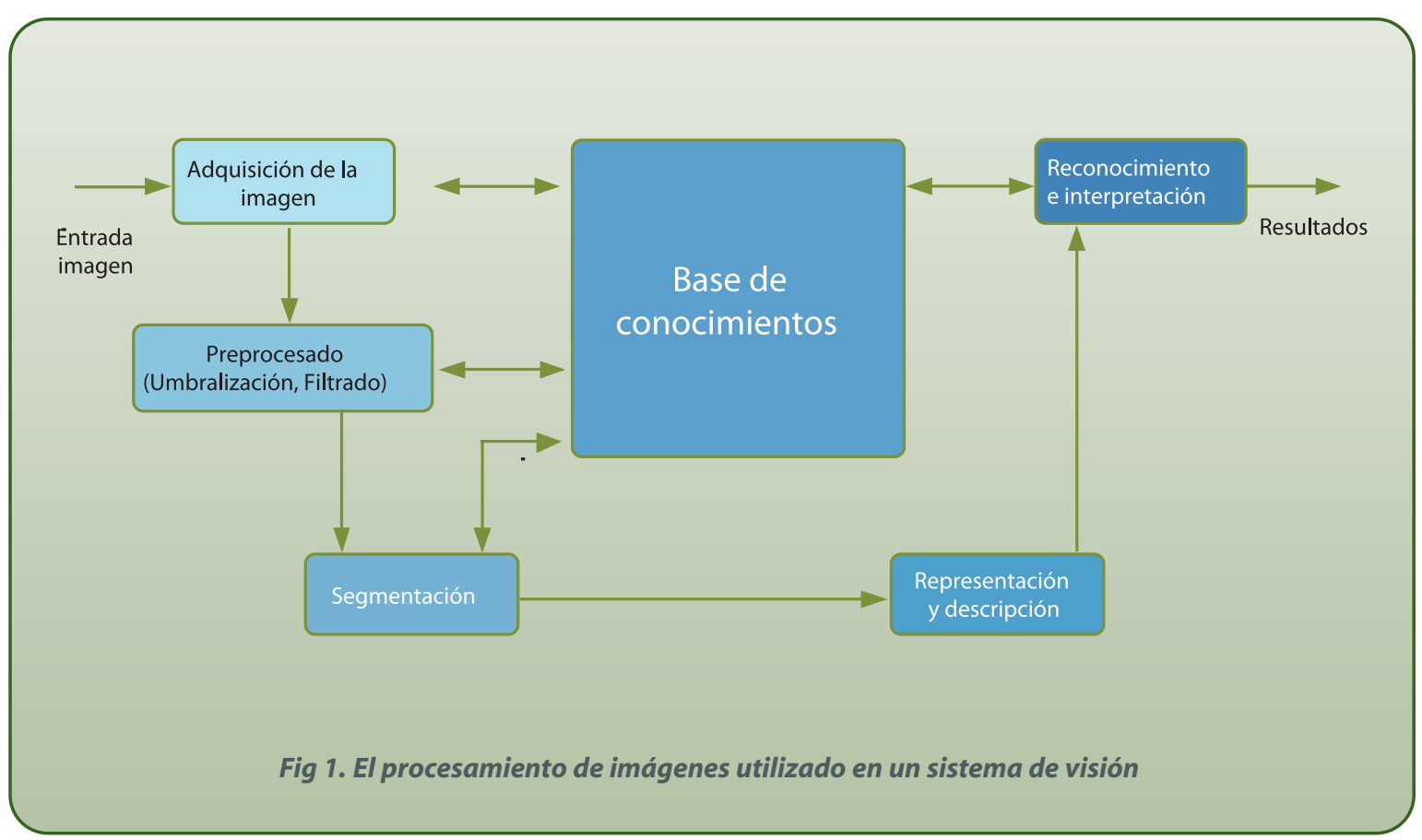

\section{Conclusión}

Estas son los partes principales en el procesamiento de imágenes, las cuales pretenden ser de análisis exhaustivo en posteriores publicaciones, se irán presentando métodos de calibración, de filtrado y otras alternativas de desarrollo en esta área.

\section{IU. Referencias}

[1]J. Chávez \& O. Starostenko, Motion Estimation algorithms of image processing services for wide community, Japan, 2001.

\section{U. Glosario}

CCD.-Charged Coupled Device - Dispositivos de carga acoplada. 